\title{
The Representation Of Javanese Women In Damar Kurung Painting - Gresik
}

\author{
Aniendya Christianna \\ Visual Communication Design, Faculty of Art and Design Petra Christian University \\ Siwalankerto 121-131, Surabaya 60236, Indonesia \\ aniendya@petra.ac.id
}

Damar Kurung is one of the typical cultural products of Gresik that has recorded Gresik's civilization. Damar Kurung is a bamboo-framed paper lantern that has existed since Hindu-Buddhist times. This research is a qualitative research with a descriptive approach. The purpose of this research is to understand the meaning of the symbol in Damar Kurung's decorative that are painted by Masmundari. At the same time to identify the gender roles of Javanese women. The results of this study are (1) Javanese women do not reject face makeup, because using makeup is a manifestation of women's respect and acceptance in dealing with social norms; (2) Javanese women formulate their identity through a procession of traditional ceremonial preparations that are mostly carried out 'behind' (in the kitchen).

Keywords: Culture, Art and Craft, Damar Kurung, Women

\section{Representasi Identitas Perempuan Jawa Dalam Ragam Hias Damar Kurung - Gresik}

Damar Kurung merupakan salah satu produk budaya khas Gresik yang telah merekam peradaban masyarakat Gresik. Damar Kurung adalah lampion kertas berangka bambu ini sudah ada sejak zaman Hindu-Budha. Penelitian ini adalah penelitian kualitatif dengan pendekatan deskriptif. Tujuan dari penelitian ini untuk memahami makna simbol di damar kurung yang dilukis oleh Masmundari. Sekaligus untuk mengidentifikasi peran gender perempuan Jawa. Hasil dari penelitian ini adalah (1) perempuan Jawa tidak menolak riasan wajah, karena menggunakan riasan adalah perwujudan penghormatan dan penerimaan perempuan dalam menghadapi norma sosial;(2) perempuan Jawa merumuskan identitasnya melalui prosesi persiapan upacara adat yang banyak dilakukan 'dibelakang' (di dapur).

Kata Kunci: Budaya, Art and Craft, Damar Kurung, Perempuan

Peer review : 9 - 23 Agust 2018, Accepted : 3 September 2018 


\section{INTRODUCTION}

Despite the wide variety of Javanese culture, every its form reflects the personality and philosophy of Javanese life. Javanese culture is full of symbols that often teach about the wisdom of human life. Particularly, about the horizontal relationship of man and the vertical relationships of humans with god.

One form of Javanese culture is art and craft. Art and society have mutual relationships. The social and cultural background also influences the artist in producing a work of art. In creative process, the communication of everyday life, and transcendent experiences become important background. Java is one of Asian nations who uses symbolic language to express their thoughts about lives. Mythology has an important role in the use of symbolic language. Javanese culture which is full with symbols has teached the Javanese themselves about the wisdom of Javanese life. There is a complex relationship between art and society. An art work produced by an artist who also born from a society with a complex social and cultural background. The aesthetic-artistic experience of art, community experience, and transcendent experience become an important background in producing artwork.

Damar Kurung handicraft is one of the unique Gresik cultural products, has recorded civilization of Gresik people widely through its painting since the $16^{\text {th }}$ century. It is influenced by Hindu-Buddhist and Islamic cultures. According to the ancient Javanese plaque of Karang Bogem, 1387 $\mathrm{AD}$, Gresik city is known as a part of Majapahit Kingdom, which is located at East Java (Graaf 1989: 172). It also described in the 'Masyarakat Islam Tionghoa di Indonesia' (Budiman: 1979) that $T s^{\prime}$ 'e-te'un (Gresik) is an important port where foreign ships anchored. Gresik city as one of many old cities in Indonesia can be equated with other important old cities like Demak, Kudus, Medan, Makasar and Cirebon.

Masmundari who passed away with more than 100 years age was the last female artist who consistently conserved Damar Kurung. After her death, neither the family nor the community has the same expertise to continue the preservation of Damar Kurung. It is on the brink of extinction, as Damar Kurung collections have been scattered in domestic and foreign collectors and were not well-documented; makes it difficult to trace them back. However, the good news has come from the Ministry of Education and Culture of the Republic of Indonesia on October 4th, 2017, Damar Kurung has nominated as a national heritage (https://duta.co/damar-kurung-gresik-ditetapkan-sebagaiwarisan-budaya-tak-benda/).

Bill Holm (1973: 8) mentions that the artist's artworks of the past need to know its meaning, before actually disappeared by the time. The meaning of Damar Kurung dec-
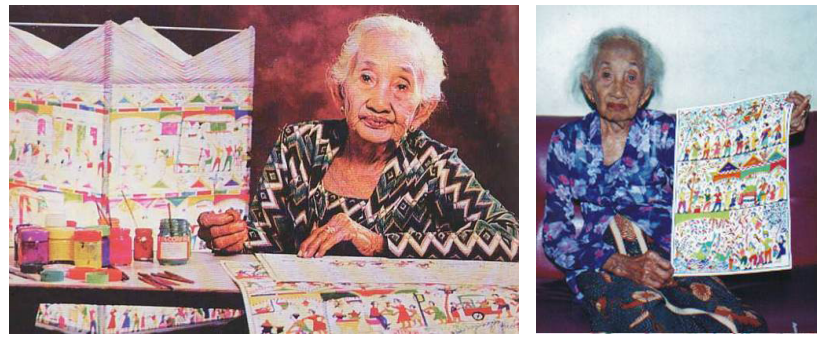

Figure 1. Masmundari

(Source: Mosaik Magazine Februari 2003: 106)

oration must also be known as early as possible, before changing and its original meaning is increasingly blurred.

\section{LITERATURE}

Gender Identity

In the Questons of Cultural Identity (1996: 17), Stuart Hall questioned 'who' and 'why' every human being needs identity. Hall mentioned that the concept of identity is something that is needed and very important. In finding out the identity of a subject required an identification process. Hall describes identification as a process of construction that is never completed, conditional, and full of uncertainty.

Gender is one of the many constructs of human identity. Gender identity is a thing that is not separate from each person and bring significant implications for the person who bears it. Gender identity encourages people to see themselves in existing categories in society, namely 'feminine' and 'masculine'. The gender identity built by the community is based on the identity of sex.

Not all humans do gender roles according to their gender identity. But the fact is society often lead people to play gender roles in accordance with their gender identity (which often refers to sexual identity). This formation of gender identity occurs naturally and has become a deeply rooted tradition in society. Through a continuous series of internalizations repeated, the meaning of gender identity can not be separated.

The identity of women both in the sex category and in the gender category is something that is given. There are still many myths that define women often defined as helpless, unequal, 'homebased', 'friends behind', and inferior in social relations. Is it true that Javanese culture builds a woman's identity in such a way?

\section{Damar Kurung and Masmundari}

Koehandari (2009:58) mentioned that Damar Kurung has been known since the days of Sunan Prapen, the 4th Sunan who ruled Giri Kedaton (1548-1605). In the form of lanterns with decorations on the paper cover. In the beginning, Damar Kurung was used as a reminder of tarawih praying in the month of Ramadan. Continued by Koehandari that Damar Kurung means as 'damar' is a light and 'damar' is a frame. So Damar Kurung is the lantern 

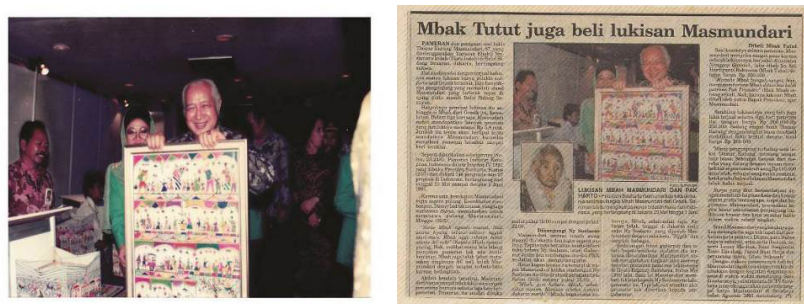

Figure 2. Clipping Mass Media Coverage (Source: Damar Kurung Institute)

that is usually ignited when the sun begins to set or before Maghrib praying.

Sriati Masmundari (1909-2015), a women blessed with long life is a Gresik artist who consistently develops and conserves Damar Kurung. Drawing on paper and arranging it into Damar Kurung. This work has been done by Masmundari's brother and her uncle. The characteristic of Masmundari's Damar Kurung is its ornament from the observation of daily culture in Gresik which is spontaneously drawn (direct observation and without sketch first). Scenes in everyday life that are the source of ideas and expressions of her work, such as market activities, traditional ceremonies, weddings, circumcision, Independence Day Celebration, religious activities and other public activities that reflect the local culture.

At first, Masmundari made Damar Kurung only to support the family. However, since November 1987, when Bentara Budaya Jakarta showcased Masmundari's work for the first time, the public began to pay more attention to this art. Imang A.W one of the painters in Gresik City guided Masmundari to change the orientation of Damar Kurung into a two-dimensional painting on wood-framed canvas paper. The changes have an impact on quality and increased marketing value of Damar Kurung (Indrakusuma, 2003: 4). Since the inaugural exhibition in Bentara Budaya Jakarta, Masmundari and Damar Kurung are increasingly known. Until May 11-15, 1990 held an exhibition titled Damar Kurung Masmundari Imagination "at Hyatt Bumi Surabaya. At the end of 1990 the invitation to exhibition came from the Government of East Java Level I Region in TMII Jakarta. On May 23 to June 1, 1991, Damar Kurung Masmundari took part in the fourth Indonesian Interior Design (KIDI) exhibition at the Senayan Convention Hall in Jakarta. On that occasion, Masmundari met and shook hands with the 2nd President of Indonesia: Soeharto, as well as demonstrating her skill in painting. Masmundari's struggle deserves appreciation because most of her age is spent to preserve this craft, alone! Damar Kurung is full of cultural values and religion, its existence on the verge of extinction since Masmundari's death in 2015.

Damar Kurung is basically a lantern made of oil paper with a bamboo blade frame that forms 3 dimensions. Each side of the oil paper is painted with a variety of ornaments depicting daily culture in Gresik. Before there was a col-

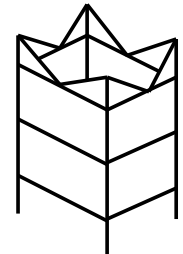

(1)

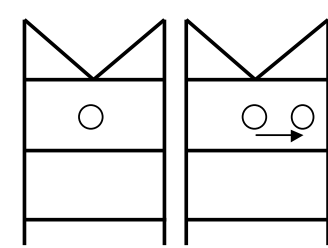

(2)

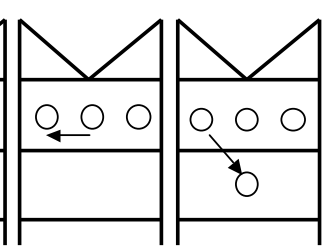

(4) $3^{\text {rd }}$ Figure. (1) Cross section of Damar Kurung; (2) Step 1 draw the object from the middle of the top of the field; (3) Step 2 draw the object to the right of the field; (4) Step 3 draw the object to the left of the field; dan (5) Step 4, after the top field is completed, proceed as the first step in the second field (bottom)

oring device on the market, Damar Kurung was stained with food coloring. The colors used in decorating Damar Kurung are red, green, yellow, dark blue, and black. These colors refer to the colors of the universe: the north is black, the west is yellow, the east is white and the south is red (Sumarjo, 2002: 285). The unique thing about the production of Damar Kurung is in organizing fields to tell a scene. Each scene is drawn with a special technique for sacred and profane scenes. Before drawing, the image area has been divided into sections. The drawing process begins from the middle-top, then moves towards the right until it fills the field. Back to the middle of the field before, left to full. And so on from top to bottom fields.

Each side of Damar Kurung has 1-2 sequences (top-down / bottom-up) on each side. On a wider field, divided into 3-4 profane scenes, by looking from bottom to top. Each sequence describes a scene. When the theme of the sacred scene, the drawing technique and the direction of reading from left to right. Masmundari paintings has a naïve style, honest, plain, spontaneous but beautiful.

\section{METHOD}

Every society has and uses certain symbols. These symbols can be tangible and abstract ideas. The shape of the symbol one of them is the picture. The meaning of a symbol can not be immediately known, but it takes a process of interpretation / interpretation. These symbols can show the values that a society believes. This qualitative research uses descriptive approach. The object lies in the use of visual metaphors that Masmundari describes in Damar Kurung. The scope of this research is limited to the original Damar Kurung ornamentation by Masmundari from 1987-1990s. Over the 1990s, Masmundari began to often get sick because of her age that has been 1 century, so the production of Damar Kurung has a lot of intervention from the family. Informants to support this data come from conservationists, founders of Damar Kurung Institute, collectors, book author of history Gresik and Culture and Sport Office of Gresik Regency. The working procedure steps of this research are: a)Contacting collectors, preservers, authors, and relevant government agencies to collect data 
(verbal and visual). b) Collecting and recording data. c) Classifying data findings based on years and themes that often appear. d) Categorizing data based on friends who relavan with the identity of women. e) Analyzing any symbol containing metaphor, based on theoretical framework Identity by: Stuart Hall (1996) and W.J.T Mitchel (2005). f) Describing the identity of women built by Javanese culture through Damar Kurung painting.

The purpose of this research is to understand the meaning of the symbols that Masmundari articulates in Damar Kurung decoration. At once to understand the context in which Damar Kurung is made in establishing the identity of Javanese women.

\section{DISCUSSION}

Masmundari usually replicates similar themes into several paintings. Based on data finding, it is found that Masmundari Damar Kurung painting theme about religious activity, economic activity, traditional ceremony, technology and foreigners. All these themes are the result of Masmundari's observation on the social condition of the Gresik community. Masmundari who was blessed with longevity had the opportunity to observe many changes in Gresik.

Religious activity in Gresik is influenced by the arrival of Sunan Giri. While the economic activity in Gresik is influenced by its strategic geographical location, on the north coast of East Java. One of Gresik's main commodities is milkfish. Every year once held a milkfish festival enlivened by the entire community of Gresik. Like most Javanese, the Gresik people also carry out traditional ceremonies to celebrate the important day. Traditional ceremonies in Javanese culture are such as: mitoni ceremony (7 months pregnancy), childbirth ceremony, circumcision, marriage, and funeral. Painting with the traditional ceremonic theme most commonly found. While the theme of technology and foreigners, not many found, but that painting describes Masmundari's observation of the technological changes taking place in Gresik. And how masmundari see foreigners (who was still colonized by the Dutch and Japanese).

\section{Women's Identity In Traditional Ceremony}

Women's identity both in sex and gender category is something that given. From the biological definition of women, women are often defined as helpless, unequal, 'orang rumahan' (people who should always stay at home), 'teman dibelakang' (a complementary friend whose position is behind), and lower in social relationships. However, is it true that Javanese culture establishes women's identity in such a way?

Based on the findings and classification of Damar Kurung, it can be said that traditional ceremony is the most popular theme made by Masmundari. Traditional ceremonies in
Table 1. Table of Findings

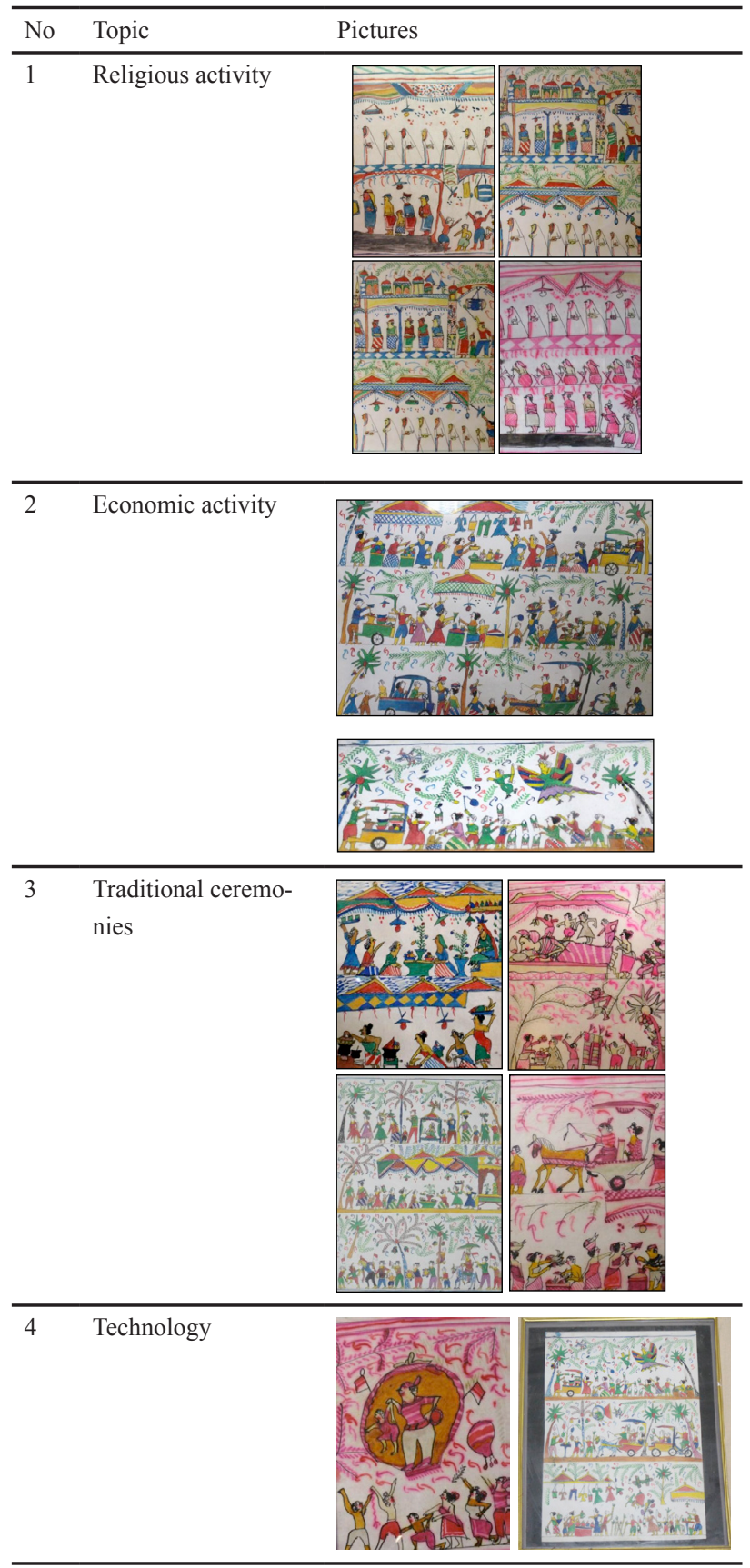

Javanese culture are held to celebrate the stage of human's life, such as : mitoni ceremony (7 months pregnancy), childbirth ceremony, circumcision, marriage, and funeral. Geertz $(1973,1976)$ proves how the conception of the Javanese world manifests in the practice of everyday life. Geertz states that traditional ceremonies unite the whole Javanese collective life in real life. The Javanese ceremony also deals with nature, such as planting season and harvest season. The ceremony in the life of Java determines the life structure of all members of society. Geertz (1973, 1976) proves how the conception of the world among the Javanese manifests in the practice of everyday life. Geertz looks at how the ceremony brings together Javanese collective life in real life. Starting from children to the elderly, 


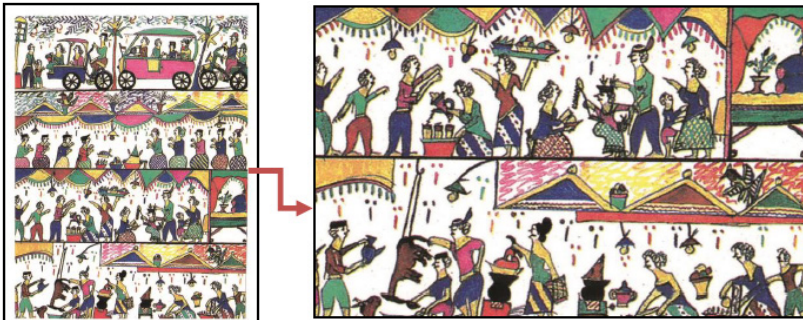

Figure 4. 'Slametan: Back Preparation' from The Decoration of Damar Kurung

(Source: Privat Documentation)

both men and women participate to contribute. Based on the decoration in Damar Kurung, it can be emphasized that the practice of Javanese ceremony is the responsibility of women.

The realization of traditional ceremony is divided into two stages : the preparation stage and the stage of prayer. Women are very dominant in Damar Kurung decoration that made by Masmundari. The preparation stage is a task for women, which includes two stages namely the front and back stage (Permanadeli, 2015: 101). While the stage of praying to God is done by men. The stage of prayer will not exist, if the preparation stage has not done by women. If women do not prepare everything well, men will not be able to pray 'face to God'. The vertical relationship between man and God in traditional ceremony is under women's control.

The back preparation stage deals with heavy and hard work, such as slaughtering goats, scattering coconuts, cooking rice on a stove, and stirring food. In Javanese culture there is a term "mbiyodo" or "rewang", it means neighbors or relatives or other women will come voluntarily to help the host prepare the ceremony. The preparation of ceremony usually does not last for a while, but at least it takes 7 days. This is a form of participation and social solidarity of Javanese women. The "back stages" performes in a traditional kitchen (which is not a fascinating place). However, the place does not limit women to establish their identity as Javanese women. Instead, from the kitchen preparation this traditional ceremony becomes a liaison between women and the social world. Through this activity, women formulates many things such as the identity of women.

The front stage is after the back stage but this stage is more 'light', such as: wrapping food and serving guests. The front stage is not like preparation stage that has many heavy and rough work. Although it is related to light work, it does not mean trivial, this job requires patience and good behavior / politeness. The preparation of traditional ceremony in the Javanese's life has been organized as a chain of work undertaken by women of any social status, any age, and level of education. Unlike in professional work, this activity does not have a clear job description. Every woman who involved should be able to know the extent

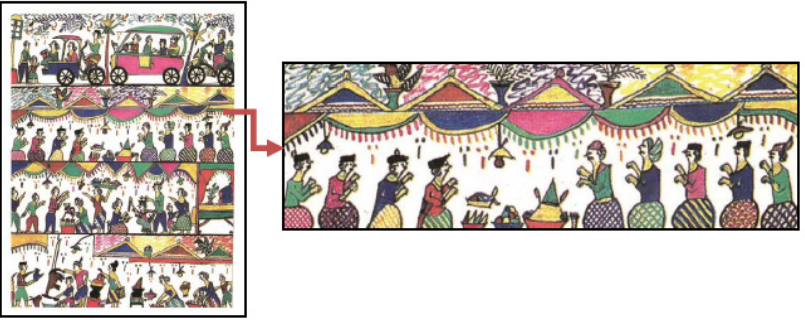

Figure 5. 'Slametan: Front Preparation' from The Decoration of Damar Kurung

(Source: Privat Documentation)

of her ability to get involved. It takes a sensitivity and humility to unite in the Javanese world. In this process, there is an exchange of information, to formulate and establish identity as a Javanese woman. Through the preparation of this ceremony the identity of Javanese women is reflected.

\section{The Beauty Of Women In Java Culture}

Although the preparation of traditional ceremony is done in the kitchen (the area behind the house which is not fascinating), it does not mean women are not required to look beautiful. Damar Kurung paint also describes the appearance of women. The faces of women are always portrayed wear red lips and white face, the color of the body remains skin color (yellow/brown/beige). Lipcolors and face powder are the basic elements of women's makeup. As stated by Martha Tilaar, Indonesian cosmetic entrepreneur (Kompas, Sunday 1 March 1998 in Permanadeli: 2015: 355) that "it seems that no Indonesian woman dares to leave the house without wearing face powder and putting lip rouge". Lip rouge is a symbol of maturity women. Only women who considered as adult are allowed to use lip rouge. However, in Javanese culture, face powder has different case from lip rouge. Face powder has been used since baby, both by women and men. At first, face powder is a flour mixture of rice with flower extract that dries in such a way as a small grain. As it comes from white rice flour, then it associated with the idea of clean, white, and fresh.

Javanese culture in Damar Kurung paint does not reject the use of make up at women. Magnis Suseno in 'Wayang dan Panggilan Manusia' (1991) mentions that the idea of women's beauty is represented by the beauty of wayang, in the figure of Sumbadra. Anderson (1982) explains something similar, that Sumbadra is the princess of a king whose face remains young, calm, deep eyes, often makes men glance at her, and she is not beautiful because of her clothes. Anderson and Magnis Suseno believe that the beauty of Javanese women come from phisical body and inner beauty. If women only focus on inner beauty, then they are considered to be "wasting the gift of the God". Meanwhile, when women too focus on the phisical body, then they are considered as do not understand the values of Javanese cultural philosophy that became the guide of Javanese's life. Wearing powder and lip rouge are not only used as make 


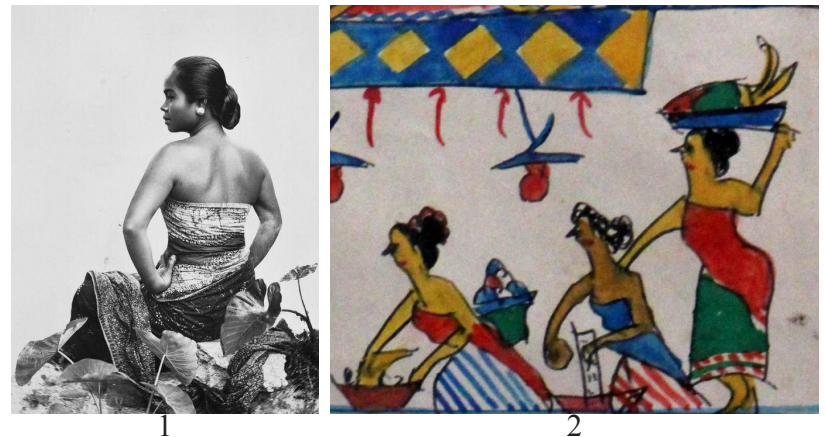

Figure 6. (1) Women figure by Masmundari

(Source: Privat Documentation);

(2) Women figure from Jawa Tempo Dulu (source: https:// id.pinterest.com/pin/448882287829882662)

up tools, but also to construct respect, acceptance and readiness, of women to face social norms in society. This means that the make up worn by women serves as a social status in Java. Women who wear makeup will be considered as ready to show themselves to the world and carry out their role in social society.

\section{CONCLUSION}

Identity is something inherent in man. Because humans live to continuously formulate an identity that signifies its existence. The cultural context in which women are born, lived and brought up contributes greatly in women builds their identity in society. Javanese culture has its own unique way of building the identity of women.

Javanese women in Gresik (representing coastal Java) plays an important role in the preparation process until the ceremony is held. Where the traditional ceremony is one of the social procession that builds the society in Javanese culture. Damar Kurung clearly shows how the performance and identity of women are defined by the community. The traditional ceremony painted by Masmundari explains that every woman involved should be able to know the extent of her abilities and where she can be involved. Every woman has the opportunity to unite herself in preparation for the ceremony. In this process, there is exchange of information, to formulate and establish identity as a Javanese woman. Through the preparation of this ceremony the identity of Javanese women is reflected. In the case of face powder and rouge, women are considered ready to show themselves to the world and are ready to carry out their role in social society. Women who wear makeup mean that they have respected and accepted the prevailing social norms, and are ready to play their respective roles. Javanese culture has a unique way to build a woman's identity, one of which is through art. Damar Kurung as one of the works of art in Javanese culture shows how culture was built. Javanese culture cannot be separated from a long history. Wherein it works the influence of Hindu-Buddhist and Islamic culture. Javanese women in
Gresik (representing the coast of Java) have an important role in traditional ceremonies, from the preparation process until the ceremony is ready. Traditional ceremonies are one of the social processes that unite people in Java. The Damar Kurung pattern clearly shows how women's performance and identity are determined by the community. It is told that every woman has the opportunity to unite herself in preparation for traditional ceremonies.

\section{REFERENCES}

\section{BOOKS}

Anderson, B.R.O.G. Mythology and The Tolerance of The Javanese. New York: Modern Asia Program Departement of Asian Studies Cornell University; 1982.

Budiman, Amen. Masyarakat Islam Tionghoa di Indonesia. Semarang: Tanjung Sari; 1979.

Geertz, C.. The Interpretation of Culture. United States of America: Basic Books Inc; 1973.

Geertz, C.. The Religion of Java. Chicago and London: The University of Chicago Press; 1976.

Graaf, H.J. de. Dan G. Th. Pigeaud. Kerajaan-Kerajaan Islam di Jawa: Kajian Sejarah Politik Abad ke-15 dan ke16 (terjemahan). Jakarta: PT. Pustaka Utama Grafiti; 1989.

Magnis-Soeseno, F. Wayang dan Panggilan Manusia. Jakarta: Penerbit PT. Gramedia Pustaka Utama; 1991.

Permanadeli, Risa. Dadi Wong Wadon. Yogyarakat: Pustaka Ifada; 2015.

Anderson, B.R.O.G. Mythology and The Tolerance of The Javanese. New York: Modern Asia Program Departement of Asian Studies Cornell University; 1982.

Budiman, Amen. Masyarakat Islam Tionghoa di Indonesia. Semarang: Tanjung Sari; 1979.

Geertz, C.. The Interpretation of Culture. United States of America: Basic Books Inc; 1973.

Geertz, C.. The Religion of Java. Chicago and London: The University of Chicago Press; 1976.

Graaf, H.J. de. Dan G. Th. Pigeaud. Kerajaan-Kerajaan Islam di Jawa: Kajian Sejarah Politik Abad ke-15 dan ke-16 (terjemahan). Jakarta: PT. Pustaka Utama Grafiti; 1989.

Hall, S. Question of Cultural Identity. London: Sage; 1996.

Haryanto., S. Seni Kriya Wayang Kulit, Seni Rupa, Tatahan dan Sunggihan. Jakarta: Pustaka Utama Grafiti; 1991. 
Holm, Bill. Northwest Coast Indian Art an Analysis of Form. Seattle and London: University of Washington Press; 1972.

Koentjaraningrat. Javanese Culture, Institute of Southeast Asian Studies, Singapore: Oxford University Press; 1985.

Indrakusuma, Danny. 90 Tahun Mengabdi Untuk Seni Tradisi Masmundari Mutiara dari Tanah Pesisir. Gresik: Pustaka Pesisir; 2003.

Lakoff, G, Metaphors We Live By. Chicago: Chicago Press University Press; 1980.

Magnis-Soeseno, F. Wayang dan Panggilan Manusia. Jakarta: Penerbit PT. Gramedia Pustaka Utama; 1991.

Permanadeli, Risa. Dadi Wong Wadon. Yogyarakat: Pustaka Ifada; 2015.

Sumarjo, Jakob. Arkeologi Budaya Indonesia. Yogyakarta: Qalam; 2002.

\section{ARTICLES}

Koentjaraningrat. Kebudayaan Nasional Indonesia Sulit Ditentukan Kepribadiannya'. Disampaikan pada Semiinar Nasional Seni Rupa dan Seni Pertunjukan dalam rangka Dies X Institut Seni Indonesia, Yogyakarta 20 Juli 1994. Dalam artikel HARIAN SURABAYA POST. Rabu, 22 Juli 1994. Hal. 7. Kol. 4; 1994.

\section{INTERNET}

https://duta.co/damar-kurung-gresik-ditetapkan-sebagaiwarisan-budaya-tak-benda/

https://id.pinterest.com/pin/448882287829882662/ 